\title{
PEMBERDAYAAN ZAKAT UNTUK MENINGKATKAN KESEJAHTERAAN MASYARAKAT PADA MASA COVID 19 DI DESA RAWAKALONG, KECAMATAN GUNUNG SINDUR, KABUPATEN BOGOR
}

\author{
${ }^{1 *}$ Ismail, ${ }^{2}$ Pujo Basuki, ${ }^{3}$ Sudjatmoko, ${ }^{4}$ Sukristian, ${ }^{5}$ Eva Kania Kurnia Rahmi, \\ ${ }^{6}$ Yayan Sudaryana \\ Universitas Pamulang, Tangerang Selatan, Banten, Indonesia \\ Email : $\underline{\text { ismail.altegali@gmail.com }}$
}

Manuskrip: Desember -2021; Ditinjau: Januari -2022; Diterima: Januari -2022; Online: Januari-2022; Diterbitkan: Januari-2022

\begin{abstract}
ABSTRAK
Pengabdian ini berjudul pemberdayaan zakat untuk meningkatkan kesejahteraan masyarakat pada masa pandemi Covid-19 di Desa Rawakalong, Kecamatan Gunung Sindur, Kabupaten Bogor. Tujuan umum dari kegiatan pengabdian kepada masyarakat ini adalah memberikan pelatihan dan pengetahuan khususnya di bidang penggunaan dan penyaluran zakat sebagai salah satu cara untuk meningkatkan kesejahteraan masyarakat di masa pandemi ini. Metode yang digunakan adalah metode survey dan penyampaian materi secara langsung serta simulasi dan diskusi mengenai pemanfaatan zakat untuk penanggulangan wabah Covid 19. Kesimpulan dan output yang akan dihasilkan dari pemecahan masalah yang diambil akan memberikan pengetahuan yang bersifat dasar bagi masyarakat di Desa Rawakalong, sehingga tujuan akhir dari kegiatan ini yaitu mewujudkan kesejahteraan bagi masyarakat sekitar dapat terwujud.
\end{abstract}

\section{Kata Kunci: Zakat, Covid 19, Kesejahteraan Masyarakat}

\section{PENDAHULUAN}

Jawa Barat merupakan salah satu Provinsi di Indonesia yang memiliki wilayah sangat luas, yaitu: $35.377,76$ KM2. Adapun secara administratif, Provinsi Jawa Barat terdiri dari 18 kabupaten, 9 kota, 627 kecamatan, 645 kelurahan, dan 5312 desa.

Desa Rawakalong merupakan salah satu Desa di wilayah Kecamatan Gunung Sindur, Kabupaten Bogor, Provinsi Jawa Barat, dengan luas wilayah 525 ha, di atas permukaan laut $125 \mathrm{M}$, dan tinggi curah hujan $2.004 \mathrm{M} 3$, yang terdapat dalam 4 dusun, 17 Rukun warga (RW) dan 68 Rukun Tetangga (RT) dan rencana pembentukan 2 Rukun Tetangga (RT) baru.

Perekonomian adalah kebutuhan setiap manusia untuk memenuhi dan mengakselerasikan tatanan kehidupan sehari-hari. Disadari atau tidak setiap interaksi terhadap perekonomian dari segi pertanian, perdagangan, dan perindustrian tidak dapat dipisahkan dengan aktivitas ekonomi, karena ekonomi 
adalah roda kehidupan yang selalu berputar yang mengantarkan manusia kearah perubahan untuk menjadi lebih sejahtera.

Kegiatan perekonomian terus berkembang dan berubah sejalan dengan perkembangan dan perubahan zaman. Pada akhir tahun 2019, dunia dihebohkan dengan sebuah kejadian munculnnya virus Covid-19. Virus ini pertama kali muncul di China, tepatnya didaerah Wuhan provinsi Hubei. Virus ini menunjukan penyebaran yang sangat signifikan cepat dan telah menimbulkan banyak kematian, sehingga WHO mengumumkan bahwa wabah yang sedang terjadi ini sebagai pandemi global.

Merespon kebijakan ini, pemerintah Indonesia menetapkan pembatasan kebijakan sosial Distancing (jaga jarak sosial, menghindari kerumunan), lalu kebijakan physical distancing (jaga jarak antara orang minimal 1 meter). Kebijakan ini menyebabkan menurunnya aktivitas dan pergerakan orang secara dratis. Akibat diterapkannya social distancing yang berubah menjadi physical distancing.

Kebijakan ini membawa pengaruh pada penurunan aktivitas ekonomi secara keseluruhan. Dalam kajian teori ilmu ekonomi physical distancing atau pembatasan aktivitas masyarakat akan berakibat pada penurunan Agregat Supply (AS) dalam perekonomian yang berdampak pada penurunan jumlah produksi atau quantity $(Q)$. Kondisi dimana masyarakat yang hanya berdiam diri dirumah (stay at home), berdasarkan hukum Supply dan Demand, lambat laun akan menyebabkan penurunan permintaan secara agregat atau Agregat Demand (AD) yang berujung pada jumlah produksi yang terus menurun. Proses penurunan perekonomian yang berantai ini bukan hanya akan menimbulkan guncangan pada fundamental ekonomi riil, melainkan juga merusak kelancaran mekanisme pasar.

Terganggunya mekanisme pasar menyebabkan terganggunya perekonomian di Indonesia. Ekonomi merupakan faktor yang terpenting dalam hidup manusia. Kebutuhan ekonomi dalam kehidupan sehari-hari manusia untuk memenuhi kebutuhannya, seperti makan, minum, pakaian, tempat tinggal, dan lain-lain memerlukan suatu ekonomi yang kuat.

Untuk Indonesia sendiri presentase penduduk miskin pada Maret 2020 sebesar 9,78\% meningkat 0,56\% terhadap September 2019. Jumlah penduduk miskin pada Maret 2020 sebesar 26,42 juta orang, meningkat 1,63 juta orang terhadap September 2019. Kemiskinan merupakan salah satu alat ukur kesejahteraan masyarakat, dengan mengukur pendapatan dan konsumsi masyarakat.

Berhubungan ketahanan setiap lapisan berbeda-beda, maka masyarakat ekonomi golongan menegah kebawah khususnya mikro dan pekerja informal berpendapatan harian tentu menjadi kelompok yang paling rentan terkena dampaknya.

Adapun yang menjadi permasalahan bagi Indonesia bagaimana Indonesia mampu melaluinya ? Apa yang dimiliki bangsa ini agar mampu bertahan di tengah gelombang wabah yang belum pasti kapan akan berakhir? Sebagai negara dengan populasi Muslim terbesar didunia, Umat Islam dapat memberikan peran terbaiknya melalui berbagai bentuk atau model Filantropi dalam ekonomi dan keuangan 
Syariah. Filantropi merupakan salah satu pendekatan untuk mempromosikan kesejahteraan termasuk didalamnya upaya mengetaskan kemiskinan. Filantropi sebagai salah satu modal sosial melalui pemberian bantuan kepada masyarakat yang kurang mampu.

Ditengah problematika perekonomian ini, solusi yang dapat ditawarkan dalam kerangka konsep dan sistem ekonomi dan keuangan Islam adalah instrument zakat. zakat adalah nama bagi sejumlah harta tertentu yang telah mencapai syarat tertentu yang diwajibkan oleh Allah untuk dikeluarkan dan diberikan kepada yang berhak menerimanya, dengan persyaratan tertentu pula.

Dalam pendistribusiannya, zakat tidak hanya lagi disalurkan dalam bentuk konsumtif saja, namun juga dalam bentuk yang produkatif. Hal ini diatur dalam UU No 23 tahun 2011 pasal 27 ayat 1 menyatakan bahwa zakat dapat didayagunakan untuk usaha dalam rangka penanganan fakir miskin dan peningkatan kualitas umat. Pendistribusian pemberdayaan zakat untuk meningkatkan kesejahteraan masyarakat yang dilakukan lembaga zakat sangat disarankan. Pengembangan zakat dapat dilakukan dengan menjadikannya sebagai modal.

Dengan segala potensi yang ada pada zakat, maka penelitian-penelitian yang relevan dengan pengelolaan zakat sangat penting dilakukan hal ini diharapkan dapat memberikan informasi lebih tentang potensi zakat dalam meningkatkan kesejahteraan masyarakat pada masa pandemi Covid-19.

\section{METODE PELAKSANAAN KEGIATAN}

Pengabdian Kepada Masyarakat (PKM) akan dilaksanakan di TPQ dan PAUD di Desa Rawakalong, Kecamatan Gunung Sindur, Kabupaten Bogor, yang berada di bawah Yayasan Hasanah Manggala Tama, yang beralamat di Komplek Permata Pamulang Blok G1, Kelurahan Bhakti Jaya, Kecamatan. Setu, Kota Tangerang Selatan pada hari Minggu tanggal 28 November 2021. Pelaksanaan akan dibimbing oleh tim pelaksana staf-staf pengajar dari Universitas Pamulang dengan mengikutsertakan peran instansi terkait baik pengelola yayasan maupun para guru TPQ dan PAUD.Metode kegiatan: Presentasi, Diskusi dan tanya jawab seputar zakat dan metode penyalurannya, tenaga pengajar Yayasan Hasanah Manggala Tama.

\section{HASIL DAN PEMBAHASAN}

Membicarakan tentang zakat tidak lepas dari pembahasan tentang persepsi harta menurut AlQur'an, terutama tentang persepsi kepemilikan yang akan meringankan si pemilik harta untuk mengeluarkan sebagian hartanya sesuai dengan ketenuan Allah swt. Lalu Allah mengizinkan manusia untuk memiliki harta tersebut dengan cara yang sudah di tentukan. Yang berarti, jika kepemilikan harta tersebut di dapat dengan cara tidak sesuai dengan aturan Allah, maka orang yang memiliki harta tersebut tidak berhak memilikinya. Seperti inilah persepsi kepemilikan harta dalam Islam yang berbeda dengan persepsi kepemilikan yang lainnya. Sehingga dapat di pahami bahwa harta kepemilikan seseorang terdapat kewajiban yang telah 
di tetapkan oleh Allah swt. dan terdapat pula hak orang lain yang keduanya sangat melekat pada harta tersebut (Hijrah Saputra, 2020).

Ciri harta yang berkah adalah dimana harta itu akan bertambah banyak, paling tidak di lihat dari segi dampak yang ditimbulkannya. Dengan berzakat, harta menjadi berkah dengan artian member rasa aman dan nyaman bagi si pemilik harta. Menjalankan kewajiban berzakat juga sang pemilik harta akan mendapatkan berkah karena lebih dekat dengan Allah swt di karenakan selalu bersyukur atas segala karunia yang telah Allah berikan. Harta yang senantiasa di zakatkan akan membantu si pemilik harta terhindar dari sikap rakus akan harta kepemilikannya, bahkan akan selalu berusaha untuk memberikan banyak manfaat bagi pemilik dan orang lain. Islam mewajibkan setiap umatnya wajib berzakat bagi muzakki (orang yang wajib berzakat) dan di berikan kepada mustahik (kelompok yang berhak menerima zakat). Hal tersebut sesuai dengan rukun Islam ketiga yaitu membayar zakat. Setiap tahun, umat Islam dengan kondisi yang berkecukupan wajib memunaikan Zakat Fitrah di bulan Ramadhan.

Terkait kondisi perekonomian saat ini, zakat dapat di gunakan sebagai alat sumber pendanaan dalam pencegahan dan pengendalian Covid-19. Akan tetapi, pengaplikasian zakat untuk hal tersebut tidak bias di gunakan secara bebas,namun harus bersumber pada patokan yang jelas supaya tidak keluar dari watas yang sudah menjadi mujma' 'alaîh tentang maşârîf zakâh (Irfandy dan Nurul Maisyal, 2020).

Hampir seluruh negara yang ada di dunia terdampak oleh pandemi covid19. Penyebaran virus ini sangat cepat, dimana awal kemunculan kasusnya bermula dari negara China, dan sekarang sudah menyebar hampir ke seluruh negara di dunia. Banyak negara yang mengalami situasi panic atau kewaspadaan tingkat tinggi dalam memutus rantai penyebaran covid-19, hal ini dilakukan agar virus tidak menyebar semakin luas. Indonesia sendiri dalam situasi pandemi menerapkan aturan social distancing bahkan dengan skala yang besar atau yang lebih dikenal dengan pembatasan sosial berskala besar (PSBB).

Aturan PSBB banyak membuat aktivitas masyarakat berkurang bahkan cenderung terhenti. Banyak industri besar yang melakukan pemutusan hubungan kerja (PHK) kepada karyawannya, usaha mikro, kecil dan menengah (UMKM) banyak yang mangkrak, jasa transportasi juga banyak berhenti bahkan industri kecil pun terdampak dalam situasi global seperti ini. Hal ini dikarenakan adanya penerapan PSBB yang dilakukan pemerintah, yang menyebabkan aktivitas ekonomi dan bisnis di Indonesia ikut terdistraksi.

Pandemi covid-19 yang terjadi di Indonesia mempunyai dampak yang cukup serius dan menimbulkan banyak keresahan di masyarakat. Hal ini dikarenakan masyarakat kehilangan pendapatannya, dimana sebelum adanya pandemi ini, masyarakat dapat menjalankan aktivitas ekonomi dan bisnis secara normal, tetapi setelah adanya covid-19 banyak aturan pembatasan yang dilakukan oleh pemerintah sehingga hal ini menyebabkan rata-rata pendapatan dari masyarakat cenderung menurun atau tidak ada pemasukan yang diterima. Oleh karena itu, apabila dibiarkan terus menerus kondisi perekonomian di Indonesia akan semakin terpuruk dan tingkat kemiskinan di Indonesia akan semakin tinggi. Hal tersebut 
dibuktikan dengan data BPS (2021) bahwa presentase penduduk miskin Indonesia semester 1 tahun 2019 sebesar 9,41 persen meningkat menjadi 10,19 persen pada semester 2 tahun 2020.

MUI mengeluarkan Fatwa Nomor 23 Tahun 2020 tentang pemanfaatan zakat, infak,dan sodaqoh di gunakan untk penanggulangan Covid-19.

Zakat merupakan pengejawantahan dari konsep "Takaful Ijtima'i, selaras dengan konsep "social insurance" dalam sistem ekonomi modern. Takaful Ijtima'i, atau social insurance adalah sebuah konsep yang mengidealkan kondisi dimana seseorang yang mengalami kesulitan tidak merasakan sendiri kesulitannya. Dalam konsep ini, kehadiran Negara saja tidak cukup untuk mengatasi berbagai persoalan yang dihadapi masyarakat terutama yang berkaitan dengan pandemi Covid-19. Perlu adanya gotong royong untuk meringankan beban sesame warga, sehingga kesulitan-kesulitan yang dihadapi khususnya berkaitan dengan masalah finansial ekonomi dapat diatasi. Zakat merupakan instrument yang ditawarkan Islam untuk merealisasikan konsep social insurance dalam kadar paling minimal, namun sangat dapat membantu meminimalisir beban atau kesulitan yang dirasakan di tengah pandemi ini.

Dari perspektif filsafat hukum Islam, pentasarufan zakat untuk penanggulangan pandemi Covid-19 selaras dengan tujuan utama penyariatan zakat, yakni saddu khillah al-muslimin atau pemenuhan dasar kaum muslim, juga selaras dengan tujuan zakat dari berbagai dimensi, seperti dimensi tarbawiyah (tujuan dalam aspek pendidikan), ijtima'iyyah (tujuan zakat sebagai penopang ekonomi) dan da'wah (tujuan zakat sebagai instrumen dakwah islam).

\section{KESIMPULAN}

Kesimpulan yang dapat diambil dari kegiatan PKM yang diselenggarakan di Yayasan Hasanah Manggala Tama,adalah sebagai berikut :

1. Tim Pengabdian Kepada Masyarakat dapat melakukan pendampingan lanjutan dengan memberikan pelatihan dan edukasi kepada tenaga pengajar Yayasan Hasanah Manggala Tama dengan harapan mampu meningkatkan kesadaran masyarakat untuk berzakat dan menyalurkannya secara tepat, sehingga bisa membantu mengatasi kesulitan yang timbul akibat pandemi covid.

2. Dengan penyaluran zakat itu diharapkan dapat menjadi penggugah bagi masyarakat lainnya yang memiliki kelebihan harta dan rezeki yang telah agar dapat turut menyalurkan zakatnya kepada masyarakat khususnya kepada masyarakat yang terdampak Covid-19. Dari sisi masyarakat yang menerima zakat, diharapkan zakat dapat menambah penghasilannya sehingga kesejahteraannya menjadi lebih baik.

Adapun saran yang ingin disampaikan yaitu tim PKM berharap dapat memberikan pelatihan dan edukasi yang berkesinambungan agar tenaga pengajar Yayasan TPQ Hasanah Manggala Tama dapat lebih baik lagi dan mampu mengoptimalkan zakat sebagai salah satu instrument untuk dapat membantu meminimalisir beban yang dirasakan di tengah pandemi ini. 


\section{DAFTAR PUSTAKA}

Azwar Iskandar dkk, "Peran Ekonomi dan Keuangan Sosial IslamSaat Pandemi Covid-19", Vol.7 No.7 Jurnal Sosial dan Budaya Syari: UIN Syarif Hidayatullah Jakarta, 2020.

Beik, Irfan Syauqi, d"Fiqh of Asnaf in The Distribution of Zakat : Case Study in The National Board of Zakat of Indonesia (BAZNAS)", al Infaq : Jurnal Ekonomi Islam, Vol. , No 2, September 2015

Felldy Utama, Fatwa MUI: Harta Zakat Boleh Dipakai untuk Penanggulangan Virus Corona diplubikasi Kamis, 23 April 2020.

Firdaus, Muhammad, "Investasi Uang zakat oleh Lembaga Zakat Menurut Pandangan Islam", dalam JII, Vol. 1 No, 2016

Hijrah Saputra, "Zakat Sebagai Sarana Bantuan Bagi Masyarakat Berdampak Covid-19," Al-Ijtima i: International Journal of Government and Social Science 5, no. 2 (2020): 161-75, https://doi.org/10.22373/jai.v5i2.

Irfandi EZ dan Nurul Maisyal, "Pendayagunaan Zakat Untuk Penanggulangan Pandemi Covid-19 Perpektif Filsafat Hukum Islam," Al - Muamalat: Jurnal Hukum dan Ekonomi Syariah 5, no. 1 (2020): 1-26, https://doi.org/10.32505/muamalat.v5i1. 1849

Yuangga, K. D., et al. (2021). Penyuluhan Management Creative Dalam Mendongkrak Inovasi Dan Memajukan Usaha Pada Sai Silver Bali. Jurnal Pengabdian Dharma Laksana, 4(1), 46-52. 